\title{
PERKULIAHAN DENGAN MODEL PEMBELAJARAN JIGSA $W$ BERBANTUAN MEDIA PRESENTASI POWERPOINT DISERTAI VISUAL BASIC APPLICATIONS UNTUK MENINGKATKAN KEMAMPUAN KOMUNIKASI MATEMATIS MAHASISWA
}

\author{
Aloisius Loka Son ${ }^{1}$, Zulkaidah Nur Ahzan² \\ ${ }^{1}$ Universitas Timor, Jln. KM 9 Kel. Sasi-Kab TTU-Timor-NTT, elson44@ ymail.com \\ ${ }^{2}$ Universitas Timor, Jln. KM 9 Kel. Sasi-Kab TTU-Timor-NTT, idhamanieszt@gmail.com
}

\begin{abstract}
ABSTRAK
Kemampuan komunikasi matematis sangat penting bagi mahasiswa calon guru matematika agar mampu mengkomunikasikan ide matematisnya baik secara lisan maupun tertulis kepada orang lain dengan jelas, tepat, dan efektif. Karena itu mahasiswa calon guru matematika perluh dibekali dengan kemampuan komunikasi matematis ketika menempuh perkuliahan melalui model perkuliahan yang berpusat pada mahasiswa dengan memanfaatkan teknologi informasi dan komunikasi yang selalu berkembang, sehingga dilakukan penelitian ini dengan tujuan untuk meningkatkan kemampuan komunikasi matematis mahasiswa melalui model pembelajaran Jigsaw berbantuan media presentasi powerpoint disertai visual basic applications. Penelitian ini merupakan jenis penelitian kuasi eksperimen yang dilakukan pada mahasiswa semester III Program Studi Pendidikan Matematika Universitas Timor tahun akademik 2015/2016. Teknik pengumpulan data yang digunakan adalah tes kemampuan komunikasi matematis. Sedangkan teknik analisa data yang digunakan adalah uji ketuntasan rata-rata, uji beda rata-rata, dan uji effect size. Hasil penelitian menunjukkan bahwa kemampuan komunikasi matematis mahasiswa yang diajarkan dengan model pembelajaran Jigsaw berbantuan media presentasi powerpoint disertai visual basic applications lebih baik dari kemampuan komunikasi matematis mahasiswa yang diajarkan dengan model pembelajaran konvensional, dengan besarnya Effect size dalam kategori besar yakni 0,92 .
\end{abstract}

Kata kunci: Pembelajaran Kooperatif Tipe Jigsaw, Media Presentasi
Powerpoint, Visual basic

\begin{abstract}
The ability of mathematical communication is very important for prospective students of mathematics teachers, in order to be able to communicate their mathematical ideas both orally and in writing to others clearly, precisely and effectively. Therefore, prospective students of mathematics teachers need to be equipped with mathematical communication skills when taking the lecture through a student-centered lecture model and utilizing the ever-evolving information technology and communication, so this research aims to improve student's mathematical communication skills through Jigsaw learning model assisted by media presentation powerpoint accompanied visual basic applications. This research is a kind of quasi experimental research conducted on a secondyear student of Mathematics Education Study Program of University of Timor in 2015/2016 academic year. Data collection techniques that is used are test of mathematical communication skills. While the data analysis technique that is used is the one sample t test, two sample t test, and effect size test. The results showed that student's mathematical communication skills taught by Jigsaw learning model with powerpoint presentation media along with visual basic applications better than the student's mathematical communication skills taught by conventional learning model with the size of the effect size in the big category that is 0.92 .
\end{abstract}

Keywords: Jigsaw Type Cooperative Learning, Powerpoint Presentation Media, Visual basic applications, Ability of Mathematical Communication. 
applications, Kemampuan

Komunikasi matematis.

How to Cite: Son, A. L., \& Zulkaidah, N. A. (2017). Perkuliahan dengan Model Pembelajaran Jigsaw Berbantuan Media Presentasi Powerpoint Disertai Visual Basic Applications untuk Meningkatkan Kemampuan Komunikasi Matematis Mahasiswa. Mathline: Jurnal Matematika dan Pendidikan Matematika, Vol.2, No.2, 109-118.

\section{PENDAHULUAN}

Matematika di sekolah bertujuan untuk membekali siswa dengan kemampuan berpikir logis, analitis, sistematis, kritis, dan kreatif, serta kemampuan bekerja sama. Kompetensi tersebut diperlukan agar siswa memiliki kemampuan memperoleh, mengelola, dan memanfaatkan informasi untuk bertahan hidup pada keadaan yang selalu berubah, tidak pasti, dan kompetitif. Tujuan di atas secara rinci ditegaskan dalam Permendiknas No 22 Tahun 2006 (Son, 2013) memuat tentang kecakapan dan kemahiran matematika yang diharapkan dapat tecapai dalam belajar matematika, yaitu (1) menunjukkan pemahaman konsep matematika yang dipelajari, menjelaskan keterkaitan antara konsep dan mengaplikasikan konsep atau logaritma secara luwes, akurat, efisiensi, dan tepat dalam pemecahan masalah, (2) memiliki kemampuan mengkomunikasikan gagasan dengan simbol, tabel, grafik atau diagram untuk mempelajari keadaan atau masalah, (3) menggunakan penalaran pada pola, sifat atau melakukan manipulasi matematika dalam membuat generalisasi, menyusun bukti, atau menjelaskan gagasan dan pernyataan matematika, (4) menunjukkan kemampuan strategik dalam membuat (merumuskan), menafsirkan dan menyelesaikan model matematika dalam pemecahan masalah, dan (5) memiliki sikap menghargai kegunaan matematika dalam kehidupan yaitu memiliki rasa ingin tahu, perhatian, dan minat dalam mempelajari matematika, serta sikap ulet dan percaya diri dalam pemecahan masalah.

Kecakapan dan kemahiran matematika yang diharapkan pada point ke-2 menggambarkan bahwa kemampuan komunikasi matematis merupakan bagian yang tak terpisahkan dari sejumlah kemampuan yang harus dimiliki siswa dalam mempelajari matematika. Ketika komunikasi ditekankan dalam pembelajaran matematika, siswa akan memiliki banyak kesempatan untuk mengembangkan keterampilan mereka. Dalam rangka pemahaman konsep-konsep matematika dan memecahkan masalah matematika, siswa harus mampu membaca dan menginterpretasikan informasi, mengungkapkan pikiran mereka secara lisan dan tertulis, mendengarkan orang lain, dan berpikir kritis tentang ide- 
ide matematika. Viseu \& Oliveria (2012) mengatakan bahwa melalui komunikasi dapat merangsang siswa untuk berbagi ide, pikiran, dugaan dan solusi matematika.

Ontario Ministry of Education (2005) mengatakan bahwa komunikasi matematis adalah proses mengekspresikan ide-ide dan pemahaman matematika secara lisan, visual, dan tertulis, menggunakan angka, simbol, gambar, grafik, diagram, dan kata-kata. Seiring dengan definisi di atas, dirumuskan indikator kemampuan komunikasi matematis menurut Sumarmo (Son, 2015) yaitu (1) menghubungkan benda nyata, gambar, dan diagram ke dalam ide matematika, (2) menjelaskan ide, situasi, dan relasi matematika secara lisan atau tulisan, dengan benda nyata, gambar, grafik, dan aljabar, (3) menyatakan peristiwa seharihari dalam bahasa/simbol matematika, (4) mendengarkan, berdiskusi, dan menulis tentang matematika, (5) membaca presentasi matematika evaluasi dan menyusun pertanyaan yang relevan, (6) menyusun argumen, merumuskan definisi, dan generalisasi.

Pencapaian kemampuan komunikasi matematis siswa sangat ditentukan oleh penggunaan model pembelajaran yang menitipberatkan partisipasi siswa melalui komunikasi lisan (oral communication) dan komunikasi tertulis (written communication). Salah satu model pembelajaran yang memacuh berkembangnya kemampuan komunikasi matematis adalah pembelajaran kooperatif tipe Jigsaw karena model pembelajaran ini menuntut setiap siswa menjadi ahli dalam topik tertentu dan menjelaskan topik keahliannya secara lisan dan tertulis kepada teman lainnya. Selain itu juga didukung dengan hasil penelitian oleh Ahmad \& Jazuli (2009) yang mengatakan bahwan kemampuan komunikasi matematis siswa yang diajarkan dengan model pembelajaran kooperatif tipe Jigsaw lebih baik dari siswa yang diajarkan dengan model konvensional.

Model pembelajaran tipe Jigsaw sering disebut sebagai pembelajaran Tim Ahli, karena setiap anggota kelompok dituntut untuk menjadi ahli dalam subtopik tertentu. Hal ini ditegaskan oleh Rusman (2011) bahwa siswa bekerja sama untuk menyelesaikan tugas kooperatifnya dalam 1) belajar dan menjadi ahli dalam sub topik bagiannya, 2) merencanakan bagaimana mengajarkan subtopik bagiannya kepada anggota kelompoknya semula. Setelah itu siswa tersebut kembali lagi ke kelompoknya masing-masing sebagai "ahli" dalam subtopiknya dan mengajarkan informasi penting dalam subtopik tersebut kepada teman-temannya. Ahli dalam subtopik lainnya juga bertindak serupa, sehingga seluruh siswa bertanggung jawab untuk menunjukkan penguasaannya terhadap seluruh materi yang ditugaskan kepadanya. 
Langkah-langkah pembelajaran Jigsaw versi Slavin menurut Trianto (2011) adalah (1) Orientasi, Guru memberikan kesempatan kepada siswa untuk belajar konsep/topik secara keseluruhan (bisa berupa tugas yang sebelumnya harus dibaca di rumah), (2) Pengelompokan, pembentukan kelompok berdasarkan rangking siswa, (3) Pembentukan dan pembinaan kelompok ahli (expert), (4) Diskusi (pemaparan) kelompok ahli dalam grup, siswa ahli dalam konsep tertentu ini, masing-masing kembali dalam grup semula dan mempresentasikan keahliannya kepada grupnya masing-masing, (5) Tes (penilaian), guru memberikan tes tertulis untuk dikerjakan oleh siswa, dan (6) Pengakuan kelompok, penilaian pada pembelajaran kooperatif berdasarkan skor peningkatan individu, tidak didasarkan pada skor akhir yang diperoleh siswa, tetapi berdasarkan seberapa jauh skor itu melampaui rata-rata skor sebelumnya.

Ilustrasi langkah utama pembelajaran kooperatif tipe Jigsaw seperti gambar berikut.

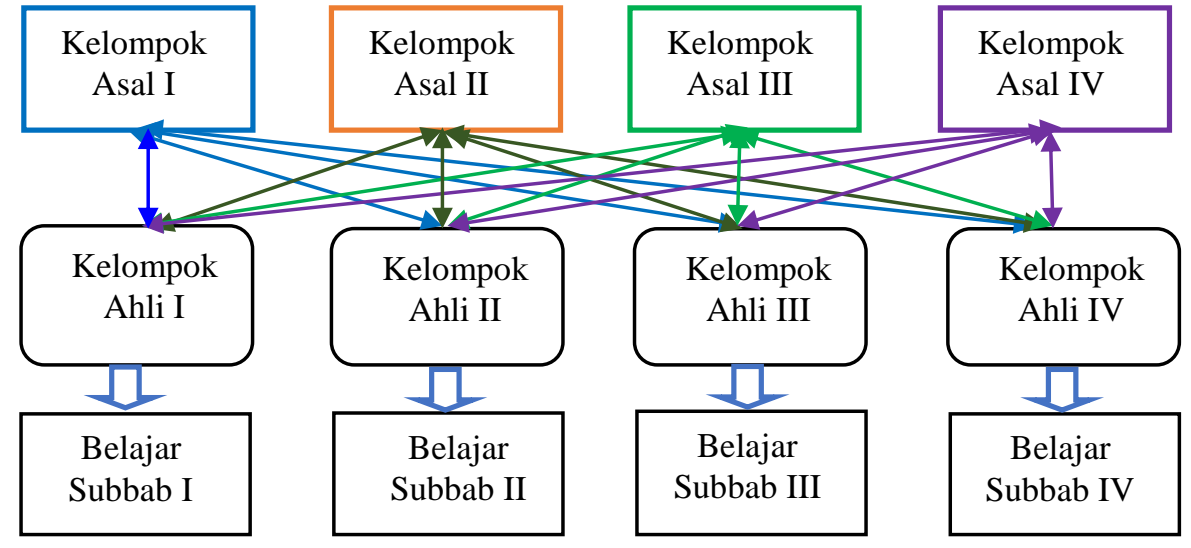

Gambar 1. Pengembangan Ilustrasi Langkah

Pada langkah orientasi sebagai langkah pertama model pembelajaran pembelajaran Jigsaw, guru memberikan kesempatan kepada siswa untuk belajar konsep/topik secara keseluruhan (scanning read) yang bisa berupa tugas yang sebelumnya harus dibaca di rumah. Terkait dengan langkah ini, guru perluh menyediakan bahan ajar seperluhnya untuk dibagikan kepada siswa selain mereka mencari sendiri literature yang lain. Prastowo (2011) menegaskan bahwa pembelajaran yang menarik, efektif, dan efisien membutuhkan bahan ajar yang dikembangkan sendiri oleh guru. Jika bahan ajar dibuat oleh guru, pembelajaran akan menjadi lebih menarik dan mengesankan bagi siswa. Selain itu, kegiatan pembelajaranpun tidak membosankan dan tidak menjenuhkan.

Salah satu jenis bahan ajar berdasarkan bentuknya adalah bahan ajar interaktif yang merupakan kombinasi dari dua media atau lebih meliputi audio, teks, grafik, gambar, animasi, dan video yang oleh penggunanya diberi perlakuan untuk mengendalikan suatu 
perintah dan perilaku alami dari suatu presentasi. Seiring dengan itu, salah satu jenis bahan ajar berdasarkan cara kerjanya adalah bahan ajar berbasis computer, yaitu berbagai jenis bahan ajar non cetak yang membutuhkan computer untuk menayangkan sesuatu dalam proses belajar. Jenis bahan ajar interaktif maupun jenis bahan ajar berbasis computer tentunya dapat diwujudkan dengan memanfaatkan program aplikasi komputer. Dalam rangka mendukung proses pembelajaran matematika yang interaktif kita dapat memanfaatkan program aplikasi yang selama ini telah dikenal seperti Microsoft Powerpoint. Program ini dapat membantu proses pembelajaran matematika yang dinamis dan interaktif. Selain itu dengan animasi yang ada pada program ini dapat lebih mudah dalam membelajarkan konsep-konsep matematika.

Program Powerpoint merupakan salah satu software yang dirancang secara khusus untuk mampu menampilkan program multimedia dengan menarik, mudah dalam pembuatan, mudah dalam penggunaan dan relative murah karena tidak membutuhkan bahan baku selain alat untuk penyimpanan data, (Susilana \& Riyana, 2007). Aplikasi Powerpoint menyediakan fasilitas slide untuk menampung pokok-pokok pembicaraan yang akan disampaikan pada siswa. Dengan fasilitas animasi, suatu slide dapat dimodifikasi dengan menarik. Begitu juga dengan adanya fasilitas front picture, sound dan effect dapat dipakai untuk membuat suatu slide yang bagus.

Bekerja pada Microsoft Powerpoint akan sangat efektif dan efisien sesuai kebutuhan, oleh karena fasilitas menu yang lengkap tergantung kemampuan desainer untuk mengekspresikan ide dan pikiran sesuai materi presentasi. Selain itu juga dapat dipadukan dengan software-software lainnya yang dapat mengakhibatkan media power point semakin kompleks dan menarik. Banyak software yang dapat digunakan untuk mengekspresikan konten presentasi, dan salah satunya adalah visual basic applications.

Visual basic applications merupakan software untuk membuat program komputer berbasis windows. Microsoft visual basic menggunakan bahasa pemprograman basic (beginner all purpose symbolic instruction code) yang merupakan salah satu bahasa pemprograman tingkat tinggi yang sedehana dan muda untuk dipelajari. Dengan visual basic kita dapat menciptakan suatu program dengan beberapa keunggulan, diantaranya mudah digunakan dan mudah dikembangkan akan tetapi tidak mengurangi kualitas dan keindahan desain programnya. Salah satu tujuan dari program visual basic adalah mendesain evaluasi berbentuk pilihan ganda. Soal-soal pilihan ganda yang telah disediahkan dalam media presentasi powerpoint dihiperlink ke visual basic applications 
sehingga memberikan interaktif saat mengerjakan soal-soal tersebut. Interaktif yang dimaksud seperti memberikan keterangan yakin dan tidak yakin atas opsi jawaban yang dipilih, serta pada akhirnya dapat diketahui total skor yang diperoleh. Hal ini tentunya menuntut pembaca (siswa) untuk terus belajar sehingga memperoleh skor maksimal setelah menyelesaikan soal-soal pilihan ganda tersebut.

Pembelajaran dengan model kooperatif tipe Jigsaw berbantuan media presentasi Powerpoint disertai visual basic applications tentunya akan sangat menarik karena desain bahan ajar dapat dikemas dengan gerakan animasi sesuai kebutuhan, serta evaluasi didesain dengan visual basic applications untuk mengukur kemampuan mahasiswa setelah mempelajari materi pelajaran yang ada dalam Powerpoint tersebut. Media presentasi yang telah didesain peneliti, dibagikan kepada semua mahasiswa untuk dipelajari sebagai tahapan scanning read dalam model pembelajaran kooperatif tipe Jigsaw. Inilah alasan mendasar yang menginspirasi peneliti untuk melakukan penelitian dengan model pembelajaran kooperatif tipe Jigsaw berbantuan media presentasi powerpoint disertai visual basic applications untuk meningkatkan kemampuan komunikasi matematis mahasiswa.

\section{METODE PENELITIAN}

Penelitian ini merupakan jenis penelitian kuase eksperimen. Creswell (2015) mendefinisikan bahwa penelitian kuase eksperimental merupakan penelitian yang melibatkan penempatan (tetapi bukan penempatan random) partisipan ke kelompok. Hal ini karena eksperimenter tidak dapat meciptakan kelompok secara artificial untuk eksperimennya.

Oleh karena merupakan penelitian kuase eksperimen sehingga peneliti menggunakan kelas yang telah ada yakni secara random (acak kelas) menentukan dua kelas dari tiga kelas mahasiswa semester III Program Studi Pendidikan Matematika Universitas Timor yaitu semester IIIB yang berjumlah 26 Orang, dan semester IIIC yang berjumlah 26 orang pula. Mahasiswa semester IIIC sebagai kelas perlakuan, sedangkan kelas kontrolnya adalah mahasiswa semester IIIB. Lamanya waktu eksperimen yakni dua kali pertemuan yang disesuaikan dengan materi perkuliahan menghitung luas daerah yang dibatasi oleh suatu kurva.

Selama dua kali pertemuan, kelas perlakuan diajarkan dengan model Jigsaw berbantuan media presentasi powerpoint disertai program visual basic, sedangkan kelas 
control diajarkan dengan model yang selama ini digunakan (konvensional). Teknik pengumpulan data yang digunakan adalah tes kemampuan komunikasi matematis.

Analisis kemampuan komunikasi matematis mahasiswa menggunakan uji ketuntasan rata-rata, uji beda rata-rata, dan effect size. Uji ketuntasan rata-rata dilakuakn menggunakan SPSS untuk mengetahui pencapain kriteria Ketuntasan Minimal (KKM) yang telah ditentukan yaitu sebesar 65. Uji beda rata-rata juga dilakuakn menggunakan SPSS untuk membandingkan kemampuan komunikasi matematis mahasiswa kelas perlakukan dan kelas kontrol. Sedangkan effect size merupakan uji statistic untuk mengetahui besarnya effect perkuliahan dengan model Jigsaw berbantuan media presentasi powerpoint disertai program visual basic yang dihitung dengan rumus $d=\frac{R_{E C}-R_{C C}}{s}$, menurut Cohen (Fröhlich, et al., 2009), dengan $\bar{x}_{E G}, \bar{x}_{\mathscr{C G}}$, dan $s$ adalah nilai rata-rata kelas eksperimen, nilai rata-rata kelas kontrol, dan standar deviasi gabungan.

\section{HASIL DAN PEMBAHASAN}

Data kemampuan komunikasi mahasiswa kelas perlakuan dan kelas control yang telah terkumpul melalui tes, selanjutnya dianalisa seperti rincian berikut.

Tabel 1. Group Statistics

\begin{tabular}{cccccc}
\hline & Grup & N & Mean & Std. Dev. & Std. Error Mean \\
\hline \multirow{2}{*}{ KKM } & Kls Perlakuan & 26 & 75,08 & 5,067 &, 994 \\
& Kls Kontrol & 26 & 70,00 & 5.953 & 1,168 \\
\hline
\end{tabular}

\section{Uji Ketuntasan Rata-rata.}

Uji ketuntasan rata-rata masing-masing kelas seperti pada tabel output SPSS berikut.

Tabel 2. One-Sample Test Kelas Perlakuan

\begin{tabular}{lccccccc}
\hline & \multicolumn{6}{c}{ Test Value = 65 } \\
\cline { 2 - 4 } & T & df & $\begin{array}{c}\text { Sig. (2- } \\
\text { tailed) }\end{array}$ & Mean Diff. & \multicolumn{2}{c}{ 95\% Conf. Int. of the Diff. } \\
\cline { 7 - 8 } & & & & Lower & Upper \\
\hline Kls_Perlakuan & 10,14 & 25 & 000 & 10,077 & 8,03 & 12,12 \\
\hline
\end{tabular}

Tabel one sampel test kelas perlakuan diatas menunjukkan bahwa nilai sig. $=0,00<$ 0,05 yang berarti bahwa rata-rata kemampuan komunikasi matematis mahasiswa kelas perlakuan berbeda dengan standar ketuntasan yang ditetapkan yakni 65. Oleh karena berbeda dan rata-rata kemampuan komunikasi matematis mahasiswa kelas perlakuan adalah 75,05 > 65, sehingga disimpulkan bahwa kemampuan komunikasi matematis kelas 
perlakuan mencapai standar yang ditetapkan. Sedangkan output SPSS One-Sample Test kelas kontrol seperti berikut.

Tabel 3. One-Sample Test Kelas Kontrol

\begin{tabular}{lcccccc}
\hline & \multicolumn{6}{c}{ Test Value = 65 } \\
\cline { 2 - 7 } & T & df & $\begin{array}{c}\text { Sig. (2- } \\
\text { tailed) }\end{array}$ & Mean Diff. & \multicolumn{2}{c}{ 95\% Conf. Int. of the Diff. } \\
\cline { 6 - 7 } & & & & Lower & Upper \\
\hline Kls_Kontrol & 4,283 & 25 &, 000 & 5,000 & 2,60 & 7,40 \\
\hline
\end{tabular}

Tabel one sampel test kelas kontrol diatas menunjukkan bahwa nilai sig. $=0,00<$ 0,05 yang berarti bahwa rata-rata kemampuan komunikasi matematis mahasiswa kelas kontrol berbeda dengan standar ketuntasan yang ditetapkan. Oleh karena berbeda dan ratarata kemampuan komunikasi matematis mahasiswa kelas kontrol adalah $70>65$, sehingga disimpulkan bahwa kemampuan komunikasi matematis kelas kontrol mencapai standar.

Oleh karena rata-rata kemampuan komunikasi matematis mahasiswa kelas perlakuan maupun kelas control mencapai standar yang ditentukan sehingga dapat dilanjutkan dengan analisis two sample t test.

\section{Uji Beda Rata-rata.}

Uji beda rata-rata ini dilakukan dengan tujuan untuk menguji hipotesis apakah terdapat perbedaan kemampuan komunikasi matematis mahasiswa yang dijarakan dengan model Jigsaw berbantuan media presentasi powerpoint disertai program visual basic dengan mahasiswa yang diajarkan dengan model konvensional. Hasil analisisnya seperti tabel output SPSS berikut.

Tabel 4. Independent Samples Test

\begin{tabular}{|c|c|c|c|c|c|c|c|c|c|c|}
\hline & & $\begin{array}{r}\text { Lev } \\
\text { Tes } \\
\text { Eq. } 0\end{array}$ & $\begin{array}{l}\text { ne's } \\
\text { for } \\
\text { Var. }\end{array}$ & & & est for $E$ & quality & of Mea & Ins & \\
\hline & & \multirow[t]{2}{*}{$\mathbf{F}$} & \multirow[t]{2}{*}{ Sig. } & \multirow[t]{2}{*}{$\mathbf{t}$} & \multirow[t]{2}{*}{ df } & \multirow[t]{2}{*}{$\begin{array}{l}\text { Sig. (2- } \\
\text { tailed) }\end{array}$} & \multirow[t]{2}{*}{$\begin{array}{c}\text { Mean } \\
\text { Diff. }\end{array}$} & \multirow[t]{2}{*}{$\begin{array}{l}\text { Std. } \\
\text { Error } \\
\text { Diff. }\end{array}$} & \multicolumn{2}{|c|}{$\begin{array}{c}95 \% \text { Conf. } \\
\text { Int. of the } \\
\text { Diff. }\end{array}$} \\
\hline & & & & & & & & & Lower & Upper \\
\hline \multirow{2}{*}{ KKM } & $\begin{array}{l}\text { Equal var. } \\
\text { assumed }\end{array}$ & \multirow[t]{2}{*}{,441 } & \multirow[t]{2}{*}{, 510} & 3,311 & 50 & ,002 & 5,077 & 1,533 & 1,998 & 8,156 \\
\hline & $\begin{array}{c}\text { Equal var. } \\
\text { not ass. }\end{array}$ & & & 3,311 & 48,76 & ,002 & 5,077 & 1,533 & 1,996 & 8,158 \\
\hline
\end{tabular}

Nilai Sig. pada kolom Levene's Test for Equality of Varience sebesar 0,510>0,05 yang berarti bahwa varians kemampuan komunikasi kelas perlakuan dan kelas control adalah sama sehingga perbedaan KKM dapat dilihat sig. pada baris Equal varience assumed. Nilai sig. (2-tailed) sebesar 0,02 <0,05 sehingga disimpulkan bahwa terdapat 
perbedaan kemampuan komunikasi matematis mahasiswa yang diajarkan dengan model Jigsaw berbantuan media presentasi powerpoint disertai program visual basic dengan mahasiswa yang diajarkan dengan model konvensional. Selanjutnya dengan rata-rata kemampuan komunikasi matematis mahasiswa secara empiris dapat digunakan untuk menentukan perbandingan antara keduanya. Rata-rata kemampuan komunikasi matematis mahasiswa kelas perlakuan sebesar 75,08, sedangkan rata-rata kemampuan komunikasi matematis mahasiswa kelas kontrol sebesar 70,00 sehingga disimpulkan bahwa kemampuan komunikasi matematis mahasiswa yang diajarkan dengan model Jigsaw berbantuan media presentasi powerpoint disertai program visual basic lebih baik dari kemampuan komunikasi matematis mahasiswa yang diajarkan dengan model konvensional.

Hal ini disebabkan dalam proses perkuliahan dengan model Jigsaw, setiap mahasiswa dituntut menjadi ahli dalam konsep tertentu, dan mampu menjelaskannya kepada anggota kelompok lainnya, seperti yang dikatakan oleh Trianto (2011) bahwa melalui Jigsaw setiap siswa dari kelompok berbeda berkumpul untuk mendiskusikan topic yang sama dari kelompok lain sampai mereka menjadi ahli pada konsep tersebut. Kemudian kembali ke kelompok semula untuk mengajarkan topik yang mereka kuasai kepada teman-teman sekelompoknya.

Terdapat kemungkinan bahwa setiap mahasiswa akan lebih cenderung menguasai topic yang didiskusikan dalam kelompok ahli. Hal ini diantisipasi dengan membagikan media presentasi powerpoint disertai visual basic applications kepada mahasiswa untuk dipelajari diluar jam kuliah sebagai langkah scanning read. Dalam media presentasi tersebut telah disediakan sejumlah soal pilihan ganda yang didesain dengan program visual basic sehingga dapat memberikan feedback saat menyelesaikan soal-soal tersebut. Mahasiswa dengan segera mengetahui jumlah skor yang diperoleh sehingga menuntut mereka untuk mengetahui indikator-indikator soal yang telah dikuasi dan belum dikuasai.

\section{Effect size}

Effect size merupakan besarnya efek yang ditimbulkan oleh parameter yang diuji di dalam pengujian hipotesis. Dalam hal ini adalah besarnya efektivitas perkuliahan dengan model Jigsaw berbantuan media presentasi powerpoint disertai visual basic applications dalam meningkatkan kemampuan komunikasi matematis mahasiswa. Hasil penelitian yang menunjukkan bahwa kemampuan komunikasi matematis mahasiswa kelas perlakuan lebih baik dari kelas control, yang secara empiris dapat dilihat dari rata-rata kemampuan 
matematika kelas perlakuan sebesar 75,08, dan kelas control sebesar 70, sehingga effect size dari perkuliahan dengan model pembelajaran Jigsaw berbantuan media presentasi powerpoint disertai visual basic applications sebesar 0,92. Nilai effect size ini berada dalam kategori besar sesuai kriteria menurut Cohen (Fröhlich, et al., 2009) tentang besar kecilnya effect size yakni efek kecil dalam interval $0<d<0,2$, dalam interval $0,2<d<0,8$, dan dalam kategori besar dalam interval $d>0,8$.

\section{KESIMPULAN}

Berdasarkan hasil penelitian dan pembahasan di atas, dapat disimpulkan bahwa kemampuan komunikasi matematis mahasiswa yang diajarkan dengan model pembelajaran Jigsaw berbantuan media presentasi powerpoint disertai visual basic applications lebih baik dari kemampuan komunikasi matematis mahasiswa yang diajarkan dengan model pembelajaran konvensional, dengan Effect size sebesar 0,92.

\section{DAFTAR PUSTAKA}

Ahmad \& Jazuli, A. (2009). Jigsaw Type of Cooperative Learning as a Means of Inproving High School Studients Mathematical Communication Abiliy. International Journal for Education Studies. 1(2), 207-218.

Creswell, J. (2015). Riset Pendidikan (Perencanan, Pelaksanaan, dan Evaluasi Riset Kualitatif dan Kuantitatif). Yogyakarta: Pustaka Pelajar.

Fröhlich, M., Emrich, E., Pieter, A., \& Stark, R. (2009). Outcome Effects and Effects Sizes in Sport Sciences. International Journal of Sports Science and Engineering. 03 (03), 175-179.

Ontario Ministry of Education. (2005). The Ontario Curriculum, Grades 1 to 8: Mathematics. Toronto, ON: Queen's Printer for Ontario.

Prastowo, A. (2011). Panduan Kreatif membuat Bahan Ajar Inovatif, Menciptakan Metode Pembelajaran yang Menarik dan Menyenangkan. Jogjakarta: Diva Press.

Rusman. (2011). Model-Model Pembelajaran, Mengembangkan Profesionalisme Guru. Jakarta: Rajawali.

Susilana, R \& Riyana, C. (2007). Media Pembelajaran. Bandung: Wacana Prima.

Son, A. L. (2013). Pembelajaran matematika dengan Model Kooperatif Tipe Jigsaw berbasis Konstruktivisme Untuk Meningkatkan Self-confidence dan Kemampuan Komunikasi matematis. Thesis. Semarang: Universitas Negeri Semarang.

Son, A. L. (2015). Pentingnya Komunikasi matematis Bagi Calon guru Matematika. Jurnal Gema Wiralodra. VII(1), 32-39.

Sumarmo, U. (2003). Pembelajaran Matematika untuk Mendukung Pelaksanaan Kurikulum Berbasis Kompetensi. Makalah. Bandung: UPI.

Trianto (2011). Mendesain Model Pembelajaran Inovatif-Progresif. Jakarta: Kencana.

Viseu, F \& Oliveria, I. B. (2012). Open-ended Tasks in the Promotion of Classroom Communication in Mathematics. International Electronic Journal of Elementary Education. 4(2), 287-300. 